Saša Krstić ${ }^{1}$

Aleksandra Fedajev

Radmilo Nikolić ${ }^{3}$
JEL: G32, M21, D24

DOI: 10.5937/industrija46-19735

UDC:658.155(497.11)"2017"

338.1(497.11)"2017"

Original Scientific Paper

\title{
Some Aspects of Business Operations of Serbian Economy in 2017
}

\author{
Article history: \\ Received: 14 November 2018 \\ Sent for revision: 21 November 2018 \\ Received in revised form: 6 December 2018 \\ Accepted: 6 December 2018 \\ Available online: 28 December 2018
}

\begin{abstract}
After a period of stagnation, caused by the global economic crisis, the Serbian economy has been transformed into a growing economy with a satisfactory level of price and currency stability. In order to maintain this trend in the future and to ensure further acceleration of economic activity, it is necessary to identify the key problems faced by companies in every economic segment. In this sense, the aim of this paper is to identify the segments of the economy with the most favourable and the disadvantageous business economy, as well as the advantages and limitations of each segment individually. To perform this comparative analysis, the ratio analysis was applied in combination with PROMETHEE and the entropy method. Research results suggested that medium enterprises and those operating in the sector of information and communication and in the region of Vojvodina had the most favourable business economics, while the micro enterprises, those who operate in the construction sector and in the region of Kosovo and Metohija were in the worst economic and financial situation. On the basis of the obtained results, appropriate recommendations and guidelines for improvement of the business economics in the worst ranked segments of the economy have been defined.
\end{abstract}

Keywords: business entities, business economics, rational analysis, PROMETHEE method, entropy method.

\footnotetext{
${ }^{1}$ University of Belgrade, Technical Faculty in Bor, skrstic@tfbor.bg.ac.rs

2 University of Belgrade, Technical Faculty in Bor

${ }^{3}$ University of Belgrade, Technical Faculty in Bor 
Krstić S., et al: Some Aspects of Business Operations of Serbian Economy in 2017

\section{Neki aspekti poslovanja srpske privrede u 2017. godini}

Apstrakt: Nakon perioda stagnacije uzrokovanog svetskom ekonomskom krizom, srpska privreda se transformisala u rastuću ekonomiju sa zadovoljavajućim nivoom cenovne i valutne stabilnosti. Kako bi se ovaj trend održao u budućnosti i obezbedilo dalje ubrzanje privredne aktivnosti potrebno je identifikovati ključne probleme sa kojima se susreću privredni subjekti u svakom segmentu privrede. U tom smislu, cilj ovog rada je da se identifikuju segmenti privrede sa najpovoljnijom i najlošijom ekonomijom poslovanja, kao $i$ prednosti $i$ ograničenja, svakog segmenta pojedinačno. Za sprovođenje ovakve komparativne analize primenjene su racio analiza i PROMETHEE $i$ entropijska metoda. Rezultati istraživanja ukazali su da su najpovoljniju ekonomiju poslovanja imali srednji privredni subjekti, oni koji posluju u sektoru informisanje i komunikacije i u regionu Vojvodine, dok su najnepovoljniji ekonomsko-finansijski položaj imali mikro privredni subjekti, oni koji posluju u oblasti građevinarstva i regionu Kosovo i Metohija. Na osnovu dobijenih rezultata definisane su odgovarajuće preporuke i smernice za unapređenje poslovanja najlošije rangiranih segmenata privrede.

Ključne reči: privredni subjekti, ekonomija poslovanja, racio analiza, PROMETHEE metoda, entropijska metoda.

\section{Introduction}

Serbian economy has been facing numerous limitations in conducting business operations over the years, the transition process is taking place with difficulties, and policymakers are still searching for the proper growth and development model (Đuričin and Vuksanović, 2014). Structural reforms are carried out slowly, thus enabling the occurrence of many negative social manifestations, such as corruption, shadow economy, moral hazard and others. Besides having a direct impact on the growth and the development of economy as a whole, the existence of economic entities involved in these activities can have a negative influence on the entities operating in the formal sector and in accordance with the principles of market economy. Even though it has been almost three decades since the beginning of transition process all the necessary reforms have not been implemented and the business environment has not changed significantly. The inconsistent, inefficient and slow implementation of reform measures resulted, not in recovery, but in so called "transition trap", i.e. a structural crisis called "transitionalism" - the state of economic and social development of continual reforms which do not come to an end with desirable effects (Đuričin, 2016). 
The disadvantages of the business environment were especially disclosed during the global financial crisis in 2008. The crisis halted the economic growth, which was stimulated by the increase of domestic demand and intensification of the reform processes after 2000, while the recovery process was difficult and long with numerous consequences for the real and financial sector of economy. The economic entities which conducted business poorly were on the brink of bankruptcy, while "healthier" companies maintained some kind of economic activity. Low level of profitability disabled increase in capital, so the growth based on self-financing was limited (Malinić, 2013). However, after several years, Serbian economy started to expand its economic activities. The growth trend continued in 2017, when the overall revenue of economic entities increased for $8.3 \%$, while overall expenditure decreased for $5.8 \%$ compared to the previous year. This change in revenue and expenditure resulted in achieving a positive financial result for the entire economy, which was increased 2.3 times compared to the previous year and amounted to 437.180 million dinars. Three-fifths of economic entities operated with a positive result (Business Registers Agency, 2018).

However, although there were noticeable signs of recovery in 2017, a large number of economic entities had problems with maintaining liquidity, indebtedness and profitability at a satisfactory level. This is supported by the National Bank of Serbia data that 53,000 companies had their bank accounts blocked that year, which is $6.2 \%$ more than in 2016. (National Bank of Serbia, 2017) Economic entities relied, as they did in the past, mostly on borrowed funds $(62.1 \%$ of operating assets were financed from these sources), and significant part of fixed assets (in the amount of 464,064 million dinars) were financed from short-term sources (Business Registers Agency, 2018). All this points to the fact that business entities have not succeeded to maintain the appropriate amount of funds for financing their business activities and optimal structure of funding sources. High levels of indebtedness and insolvency have significantly limited the growth of economic activity and reduced the possibility for financing growth and development in the future. On the other hand, insufficient investment activity of economic entities has further slowed down the implementation of the necessary structural reforms (Erić and Stošić, 2015). This way, Serbian economy remains trapped in the so called "vicious circle of reforms" (Havrylyshyn and Wolf, 1999).

Doing business in such a turbulent and disadvantageous environment imposes the need for economic entities to quickly and efficiently adapt to the new business conditions. The ability to adapt depends, to a large extent, on the size and financial position of the company, their economic activity, as well as on the characteristics of the region they operate in. Taking this in consideration, the aim of this study is to determine which groups of business entities in Serbia are most efficient in dealing with current challenges. In order to obtain the answer, the ranking of companies according to their size, 
economic activity and region they operate in, was performed, based on the corresponding ratio numbers and by applying entropy and PROMETHEE methods. The results of the ranking showed key advantages and disadvantages of certain groups of companies. These results represent a high quality information basis for creating an economic policy aimed at the increase of the economic growth and development in the future.

\section{Literature review}

Business entities in Serbia have been facing, for many years, a lot of financial and structural disturbances inherited from the previous period, which represented the key restrains for the economic growth and improvement of competitiveness of Serbian economy. This state has caused the occurrence of numerous problems in the economy with which companies encounter in everyday business, such as insolvency, increase of debts, capital reduction, lack of net working capital, high financing costs, negative effects of financial leverage, inability to finance the sustainable growth and low profitability (Malinić and Milićević, 2012).

The custom of financing fixed assets from short-term sources had notable negative effect on business operations of business entities, which resulted in negative net working capital value. In fact, transitional recession caused the deterioration of working capital and its financing sources' structure, so the lack of capital was present throughout the transition period. Great number of companies encountered insolvency and indebtedness and they were forced to take loans under extremely unfavourable conditions. Due to deficiency in capital used for financing current operations, the companies had to postpone liabilities payment to the suppliers which caused development of the insolvency chain in economy. Under these conditions, the ROA is quite low, as well as the competitiveness of companies on the world market (Aničić et al., 2017).

A great number of authors focused on the analysis of certain groups of economic entities. Most notable are those who studied business operation of different types of companies based on their size. So, based on the liquidity analysis of 794 large companies in Serbia, Milojević and Terzić (2015) concluded that these companies recorded significant reduction in liquidity during the global economic crisis. After 2010 liquidity indicators showed certain oscillations. These changes of liquidity indicators were the result of changes in the working assets structure and excessive amount of short-term liabilities which were not covered by the corresponding amount of working capital. The results of the study indicated that not all industries were equally affected by the crisis. The crisis had the greatest impact on the liquidity of companies in the construction sector, while its influence on the entertainment 
industry and trade was the least effective. Generally speaking, there has been an increase in the liquidity of large companies over the last few years.

Kuč (2015) came to the conclusion that the key characteristics of financing activity of the largest companies, according to revenue level, were overindebtedness and unfavourable maturity structure of the borrowed financing sources with the tendency for further deterioration. The financing source structure of these companies is becoming more unfavourable due to high financing costs and low profitability that disabled further increase of the original capital, thus intensifying insolvency and bankruptcy risks. Based on this, the author concluded that large companies in Serbia were not financing growth, they "were surviving".

Analysing business operations of Serbian economy for the period 2007-2013, Malinić et al., (2014) concluded that insufficient profitability was a key limiting factor of the economic growth and development. Low profitability of numerous companies was followed by low efficiency, insufficient profit margins, high borrowing costs, low ROE and deterioration of financial leverage. The emphasis in this study was on the influence of the size of the company on its vitality. Regarding this, they concluded that ROA oscillations were at the highest in small companies, making their business operations riskier than in medium and large enterprises. These companies are generally exposed to the risk of financing, resulting from an unfavourable financing source structure. On the other hand, small companies have low share of fixed costs in total expenditures, which results in lower business risk than in medium and large companies. Taking this in consideration, they indicate that policymakers should improve the conditions in which small enterprises operate given their high share in employment and income. In addition, Aničić et al., (2017) pointed out that entrepreneurship, and SME sector in general, had not achieved satisfactory expansion in Serbian economy yet because policymakers had prioritized attracting of foreign investors.

Bearing in mind that foreign direct investors were particularly interested in investing in trade, Ćuzović at al. (2012) investigated business operations of the enterprises in this segment of economy. These authors implied that, after the internationalization of trade, it expanded over the last years. Serbian market became attractive to large foreign retail chains, which led to the opening of their stores, first in larger cities, and then throughout the country. Foreign companies had serious impact on the improvement of domestic retail chains' business results which had to adjust to the new market conditions. This way, the results of trading sector's business operations as a whole was greatly improved.

The analysis of the differences in doing business in different economic activities was performed by Raćić at al. (2011). Considering the impact of indebtedness on profitability in domestic enterprises for the period before and 
after the occurrence of global economic crisis, these authors suggested that continuous deterioration of financial leverage had adversely affected business results of all companies since the beginning of the crisis. However, the highest decline in profitability was noticed in the construction sector. Enterprises operating in this sector tried to stop this trend by increase of indebtedness in 2008, but they did not succeed. Similar scenario was also present in the food industry sector, while the highest vitality was present in the agricultural sector during the crisis. One of the key factors which, in their opinion, had negative impact on financial leverage and profitability ratio, was high interest rates in this period.

Having in mind that most of the studies in this field were focused on some specific aspect of doing business, as well as on only certain groups of economic entities, the contribution of this study is primarily in analysing a large number of aspects of doing business in economic entities. The indicators of liquidity, activity, indebtedness and profitability were analysed in this study. Based on the indicators obtained by ratio analysis, the ranking of economic entities according to their size, economic activity and region they operate in was carried out, in order to perform a comparative analysis of doing business of certain groups of economic entities in 2017. This allows a wider and more comprehensive picture of business operations in Serbian economy in 2017. According to the obtained results, recommendations and guidelines for policymakers aimed at improving business operations of the enterprises, as well as for the Serbian economy in general, were defined with special emphasis on the group of the enterprises that were worst ranked.

\section{Ratio analysis of business operations in Serbian economy in 2017}

Ratio analysis represents a very important segment of financial analysis. It enables the identification and mitigation of limitations and discrepancies in business operations through the analysis and analytical interpretation of data on investment and achieved results obtained from company's balance sheet and profit and loss account, thus preventing possible financial problems in the future. In this study, such analysis of business operation was used for certain groups of economic entities based on their size, economic activity and regions, which allowed better perception of business operations in certain segments of economy and defining measures for improving operations in those segments of economy with unfavourable performances. Ratio numbers are calculated based on data from the Bulletin of Business Registers Agency (2018). 
Krstić S., et al: Some Aspects of Business Operations of Serbian Economy in 2017

\subsection{Ratio analysis of economic entities' business operations based on their size}

One of the most important criteria for classifying business entities is their size. Each category of economic subject has its own distinctiveness which greatly influences their business operations. In order to gain insight into the business economy of micro, small, medium and large business entities, the results of ratio analysis are shown in Table 1.

Table 1. Ratio indicators of economic entities' business operations in Republic of Serbia based on their size in 2017

\begin{tabular}{|c|c|c|c|c|}
\hline \multirow[b]{2}{*}{ Indicators } & \multicolumn{4}{|c|}{ Business entities by their size } \\
\hline & Large & Medium & Small & Micro \\
\hline Current ratio (CR) & 0,92 & 1,11 & 1,16 & 0,77 \\
\hline Quick ratio (QR) & 0,63 & 0,73 & 0,74 & 0,57 \\
\hline $\begin{array}{l}\text { Net working capital (per } \\
\text { employee in } 000 \text { RSD) } \\
\text { (NWC) }\end{array}$ & $-485,11$ & 486,15 & 616,55 & $-1.928,01$ \\
\hline $\begin{array}{l}\text { Customer turnover coefficient } \\
\text { (CTC) }\end{array}$ & 6,30 & 5,73 & 5,12 & 2,98 \\
\hline $\begin{array}{l}\text { Average collection period } \\
\text { (ACP) }\end{array}$ & 57,18 & 62,83 & 70,28 & 120,67 \\
\hline Fixed assets turnover (FAT) & 0,90 & 1,58 & 1,93 & 0,98 \\
\hline Assets turnover (AT) & 0,65 & 0,87 & 0,95 & 0,44 \\
\hline $\begin{array}{l}\text { Operating profit margin (in \%) } \\
\text { (OPM) }\end{array}$ & 5,83 & 4,99 & 5,96 & 2,73 \\
\hline $\begin{array}{l}\text { Net profit margin (in \%) } \\
\text { (NPM) }\end{array}$ & 6,07 & 4,02 & 4,74 & $-1,67$ \\
\hline $\begin{array}{l}\text { Return on assets (in \%) } \\
\text { (ROA) }\end{array}$ & 3,79 & 4,34 & 5,64 & 1,20 \\
\hline $\begin{array}{l}\text { Return on equity (in \%) } \\
\text { (ROE) }\end{array}$ & 7,70 & 9,58 & 11,81 & $-10,58$ \\
\hline Efficiency coefficient (EC) & 1,07 & 1,05 & 1,06 & 0,99 \\
\hline Debt ratio (in \%) (DR) & 48,77 & 63,43 & 61,85 & 92,51 \\
\hline Debt to equity ratio (DER) & 0,95 & 1,74 & 1,63 & 13,29 \\
\hline
\end{tabular}

Source: Authors' calculations.

Based on the data in Table 1, small enterprises had the most favourable liquidity position according to all the indicators. Somewhat lower indicators, but still favourable, were found for medium enterprises. Current ratio for these enterprises was above one, which is the lower limit of this indicator. However, the same limit is set for quick ratio, implying that liquidity was not at a satisfactory level, due to greater amount of inventories (for small enterprises the inventories constitute $35.9 \%$, and for medium companies it was $34.3 \%$ ). Both groups of enterprises had positive net working capital, which was not the 
case with the remaining groups of enterprises. In addition to the negative net working capital, other liquidity indicators were unfavourable for large and micro enterprises as well (they were lower than 1). Micro companies were in much worse position than large companies, given that their current and quick ratio were lower and their negative net working capital was almost 4 times higher (this difference is, to a large extent, the result of higher number of employees in large enterprises).

These results can be explained by the difference in collection period among the observed groups of economic entities. The highest customer turnover and, accordingly, the shortest average collection period (less than 2 months) can be seen in large enterprises. Somewhat lower coefficient of customer turnover and a longer average collection period was noticed in small and medium companies, while micro companies occupied the worst position in this section as well. The customer turnover coefficient was 2.1 times lower for micro business entities than for large companies which were in the most favourable position. However, if the assets turnover and fixes assets turnover are analysed, the situation is different. Both coefficients were most favourable for small companies, while they were slightly lower, but still favourable, for medium companies. The interesting thing that can be noted is that the fixed assets turnover for micro companies was higher than for large companies, but the assets turnover was lower. This can be explained by the difference in structure of business' assets of the mentioned economic entities. The fixed assets accounted for as much as $72.2 \%$ of the company's total assets in large enterprises (due to the fact that these economic entities operate in capitalintensive industries), while the share of fixed assets in total assets of micro companies was only $44.8 \%$.

Same as in the previous aspects, micro companies had the most unfavourable situation in the area of profitability. Considering that micro business entities ended 2017 with net loss of 19,954 million dinars, net profit margin and ROE were negative. However, these business entities recorded an operating profit (therefore they realized positive operating profit rate and ROA), which indicates that negative net financial result was the consequence of loss from other activities and, to a lesser extent, the loss from financing. It is interesting to note that the highest operating profit margin, ROE and ROA were recorded in small enterprises, while the highest rate of net profit margin was noticed in large business entities. This can be seen as the result of the fact that small enterprises had significant loss from financing and other activities and consequently lower net profit. On the other hand, large business entities recorded profit from financing and other activities and, therefore, they recorded higher net financial result and net profit margin. However, these entities had higher capital than small companies, which resulted in lower ROE compared to small companies. Finally, it should be noted that efficiency coefficient was lower than 1 only in micro business entities (where total 
Krstić S., et al: Some Aspects of Business Operations of Serbian Economy in 2017

expenditures exceeded total revenues), while the highest efficiency coefficient was recorded in large business entities.

The structure of financing sources was also the most unfavourable in micro business entities, which relied heavily on borrowed financing sources (almost $92.5 \%$ of financing sources were borrowed). However, large enterprises had the most favourable structure of financing sources compared to other groups of economic entities.

\subsection{Ratio analysis of economic entities' business operations based on their economic activity}

Business entity's economic activity is an important feature, which can greatly affect their business economy. Because of this, it is necessary to perform ratio analysis of economic entities' business operations which operate in different sectors. Having in mind that, according to the generally accepted classification of economic activities, there is a great number of different economic activities, and, it is necessary to distinguish those which contribute the most to the economic growth. Therefore, 10 economic activities with the highest operating revenue in 2017 were chosen for this study: $\mathbf{G}$ - Wholesale and retail trade; Repair of motor vehicles and motorcycles; C - Manufacturing; $\mathrm{D}$ - Electricity, gas, steam and air conditioning supply; $\mathrm{H}$ - Transportation and storage; F - Construction; B - Mining; A - Agriculture, forestry and fishing; J Information and communication; M - Professional, scientific and technical activities; E - Water supply; Sewerage, waste management and remediation activities. The results of the ratio analysis for these economic entities are shown in Table 2.

Based on the data shown in Table 2, it can be concluded that the most favourable liquidity position was recorded by business entities in sector B. Economic entities in this sector had the highest current ratio (1.10) and net working capital per employee (695.48). Besides this sector, sectors $\mathrm{J}$ and $\mathrm{G}$, also had the current ratio above lower limit (which is 1) and positive net working capital per employee. Other economic entities recorded unfavourable liquidity positions based on two indicators, and the worst situation was observed in sector D. However, if the quick ratio is observed, the situation is somewhat different. The most adverse quick ratio can be seen in economic entities in sector $F$, which had a slightly lower quick ratio due to greater amount of inventories than economic entities in sector D. 
Krstić S., et al: Some Aspects of Business Operations of Serbian Economy in 2017

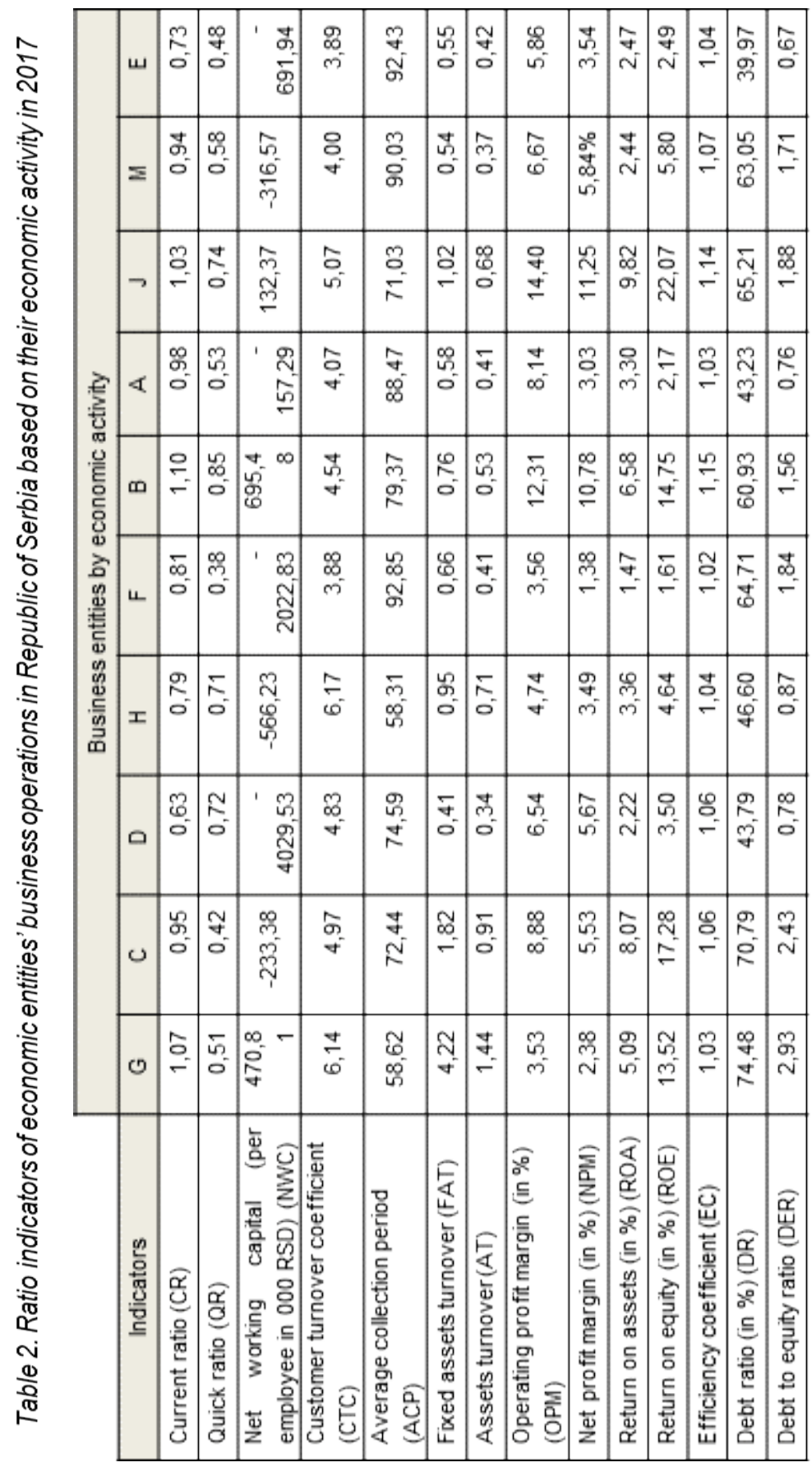


Krstić S., et al: Some Aspects of Business Operations of Serbian Economy in 2017

Liquidity of economic entities is greatly a result of asset management efficiency. The most efficient asset management was recorded in enterprises of sector $\mathrm{H}$, which had the highest customer turnover coefficient and shortest average collection period (they needed less than two months to bill accounts receivable). At the same time, enterprises in sector $F$ had the lowest customer turnover coefficient and longest average collection period of over 90 days. The lowest assets turnover and fixed assets turnover were noticed in sector D and, since there was only a slight difference between these coefficients, it can be presumed that there was a disproportion between fixed assets and current assets (in this sector, $83.35 \%$ of total assets were fixed assets ). On the other hand, economic entities in sector $G$ recorded the highest value for both mentioned indicators. Business entities in this sector had 10.3 times higher fixed assets turnover than those in sector $D$, and 4.2 times higher assets turnover than economic entities in sector D.

Considering that the primary motive for doing business is to make profit, the profitability indicators are very important for economic and financial analysis of business operations. The highest profitability can be seen in sector J, where all observed profitability indicators were at the highest compared to other groups of economic entities. The most unfavourable profitability situation was noticed in sector $\mathrm{F}$, where business entities had the lowest net profit margin, ROA and ROE. However, these enterprises did not have the lowest operating profit margin. This indicator was the lowest in sector G. As for efficiency coefficient, it was similar in all the sectors.

If the financing source structure is analysed, it can be noticed that borrowed sources were mostly used by economic entities in sector $\mathrm{G}(74.48 \%)$, and the least borrowed funds were used by enterprises in sector $E(39.97 \%)$. Based on this, companies in sector $\mathrm{G}$ had the highest capital structure ratio, while in sector $E$ this indicator had the lowest value.

\subsection{Ratio analysis of economic entities' business operations based on the region in which they operate}

In order to analyse economic entities' business operations in different regions in Serbia, it is necessary to analyse the key ratio indicators for all business entities in every region. Table 3 shows the results of the ratio analysis by regions.

Based on the liquidity indicators in Table 3, the most advantageous liquidity position was recorded by the economic entities in the regions of Eastern and Southern Serbia. Business entities in this region had the highest current ratio (1.18) and quick ratio (0.91), but they also had positive net working capital per employee. Considering that the first two indicators should be higher than one, the current ratio was at the acceptable level, while quick ratio was somewhat 
Krstić S., et al: Some Aspects of Business Operations of Serbian Economy in 2017

lower than the lower limit. Unlike these economic entities, business entities in other regions had negative net working capital per employee and, therefore, the current and quick ratios were negative as well. The least favourable liquidity indicators were noticed for enterprises in the region of Kosovo and Metohija. Short-term liabilities of the enterprises in this region (which mostly consisted of operating liabilities and other short-term liabilities), exceeded significantly the value of the current assets. What further worsened the liquidity position of these economic entities was the fact that $69.3 \%$ of the working assets consisted of receivables from sale, which indicates that there were problems with collecting these receivables.

Table 3. Ratio indicators of economic entities' business operations in Republic of Serbia based on the region in which they operate in 2017

\begin{tabular}{|l|r|r|r|r|r|}
\cline { 2 - 6 } \multicolumn{1}{c|}{} & \multicolumn{3}{|c}{ Business entities according to region they operate in } \\
\hline \multicolumn{1}{c|}{ Indicators } & $\begin{array}{c}\text { Region } \\
\text { of } \\
\text { Belgrade }\end{array}$ & $\begin{array}{r}\text { Region of } \\
\text { Vojvodina }\end{array}$ & $\begin{array}{c}\text { Region of } \\
\text { Sumadija } \\
\text { and } \\
\text { Western } \\
\text { Serbia }\end{array}$ & $\begin{array}{c}\text { Region } \\
\text { of } \\
\text { Southern } \\
\text { and } \\
\text { Eastern } \\
\text { Serbia }\end{array}$ & $\begin{array}{c}\text { Region } \\
\text { of } \\
\text { Kosovo } \\
\text { and } \\
\text { Metohija }\end{array}$ \\
\hline Current ratio (CR) & 0,92 & 0,95 & 0,91 & 1,18 & 0,31 \\
\hline Quick ratio (QR) & 0,67 & 0,60 & 0,53 & 0,91 & 0,28 \\
\hline $\begin{array}{l}\text { Net working capital } \\
\text { (per employee in 000 } \\
\text { RSD) (NWC) }\end{array}$ & $-495,54$ & $-283,99$ & $-387,27$ & 750,73 & $3.068,09$ \\
\hline $\begin{array}{l}\text { Customer turnover } \\
\text { coefficient (CTC) }\end{array}$ & 5,21 & 5,41 & 5,35 & 4,48 & 1,54 \\
\hline $\begin{array}{l}\text { Average collection } \\
\text { period (ACP) }\end{array}$ & 69,05 & 66,51 & 67,26 & 80,45 & 234,43 \\
\hline $\begin{array}{l}\text { Fixed assets turnover } \\
\text { (FAT) }\end{array}$ & 0,92 & 1,44 & 1,88 & 1,79 & 0,39 \\
\hline Assets turnover (AT) & 0,61 & 0,81 & 0,93 & 0,74 & 0,30 \\
\hline $\begin{array}{l}\text { Operating profit } \\
\text { margin (in \%) (OPM) }\end{array}$ & 5,41 & 5,52 & 4,81 & 5,28 & $-6,78$ \\
\hline $\begin{array}{l}\text { Net profit margin (in } \\
\% \text { (NPM) }\end{array}$ & 4,05 & 5,72 & 3,28 & 4,05 & 3,34 \\
\hline $\begin{array}{l}\text { Return on assets (in } \\
\% \text { ) (ROA) }\end{array}$ & 3,29 & 4,47 & 4,50 & 3,88 & $-2,00$ \\
\hline $\begin{array}{l}\text { Return on equity (in } \\
\% \text { ) (ROE) }\end{array}$ & 5,80 & 12,22 & 11,96 & 12,27 & $-21,29$ \\
\hline $\begin{array}{l}\text { Efficiency coefficient } \\
\text { (EC) }\end{array}$ & 1,05 & 1,07 & 1,04 & 1,05 & 1,03 \\
\hline Debt ratio (in \%) (DR) & 57,46 & 61,92 & 74,03 & 74,42 & 104,53 \\
\hline $\begin{array}{l}\text { Debt to equity ratio } \\
\text { (DER) }\end{array}$ & 1,35 & 1,64 & 2,88 & 3,06 & $-22,52$ \\
\hline
\end{tabular}

Source: Authors' calculations 
Economic entities in the region of Kosovo and Metohija encountered problems with collecting receivables which was supported with the customer turnover coefficient that was lower than for the enterprises in other regions, and with the average collection period of almost eight months. The situation is even more unfavourable when the two indicators for this region were compared with the same indicators for the region of Vojvodina, which had the most favourable results in this area. The customer turnover coefficient for the region of Vojvodina was 3.5 times higher than for Kosovo and Metohija, with the average collection period which was 3.5 times shorter. Besides these two mentioned activity indicators, economic entities in Kosovo and Metohija also had the lowest assets turnover and fixed assets turnover. Fixed assets accounted for as much as $76.5 \%$ of total assets of the enterprises in this region. Nevertheless, economic entities in the region of Sumadija and Western Serbia had 4.8 times higher fixed assets turnover and 3.1 times higher assets turnover than companies in Kosovo and Metohija, but also the best results in these areas compared to the enterprises in other regions.

Ensuring a satisfactory level of profitability was also a serious problem for the companies in Kosovo and Metohija, as indicated by the profitability indicators. Since they ended 2017 with business loss in the amount of 947 million dinars, the economic entities in this region recorded negative operating profit margin and ROA. ROE was also negative, which was the result of the loss above equity, which was $6.8 \%$ higher than the available capital. The positive profit rate was realized only if the net profit margin was taken into account. The interesting thing is that the net profit margin in the region of Kosovo and Metohija was higher for almost $2 \%$ than in the region of Šumadija and Western Serbia. Positive net result was realized manly because of the profit from financing, which was made due to the positive effects on exchange rate. The revenues achieved based on this were 2.3 times higher than total expenditures. However, business entities in Vojvodina were the most profitable according to all observed indicators. Finally, it should be emphasized that the efficiency coefficient was similar for all analysed regions.

Such situation in previous aspects can be seen as the result of the financial sources structure in these regions. The least favourable situation, as for the previous aspects, was in the region of Kosovo and Metohija. As a result of loss above equity, business entities in this region had debt ratio exciding $100 \%$, while the debt to equity ratio was negative. On the other hand, the best debt management indicators were found in business entities in the Belgrade region, which financed their operations equally by own and borrowed sources. 
Krstić S., et al: Some Aspects of Business Operations of Serbian Economy in 2017

\section{Methodology}

Bearing in mind a large number of criteria (ratios) that need to be considered in order to gain insight into the business economy of selected group of companies, it can be concluded that a comparative analysis of the business of certain groups of economic entities belongs to the domain of multi-criteria analysis. There are a large number of papers that are based on the application of multi-criteria analysis methods in various scientific disciplines (Marasović and Babić, 2011; Araz and Ozkarahan, 2007; Andreopoulou et al., 2018; Lopes et al., 2018), and various methods of multicriteria analysis have been developed in order to make them more adjusted to the challenges faced by decision-makers in contemporary conditions (Ishizaka and Nemery, 2013). In this paper the PROMETHEE method is applied.

An effective solving of the multi-criteria decision-making problems requires an adequate approach of weight coefficients determination, because they can greatly affect the ranking of alternatives. Bearing in mind that the topic of this paper is an analysis of a macroeconomic problem, where comparative analysis of the business economy of certain groups of enterprises should be performed objectively, it is more appropriate to use an objective approach for weight coefficients definition. One of the most commonly used methods for the objective determination of weight coefficients is the entropy method Hwang and Yoon (1981), Zeleny (1982), Zou et al., (2006).

Having in mind a large number of ratios used for the assessment of different aspect of doing business in economic entities, it is crucial to reduce the number of indicators which would be used for ranking, and carefully select a set of indicators which will best reflect the analysed problem. The correct choice of indicators is vital because it greatly influences the final research results (Hellwig, 1974). In order to assess the level of differentiation of the variables, the coefficient of variation and Pearson's correlation coefficient were used. The variable will be included in consideration if the coefficient of variation is higher than $10 \%$ and correlation coefficient between the pair of indicators is lower than 0.7 (Fura et al., 2017). Both coefficients are calculated based on all three criteria (size, economic activity and region). The variation coefficient was less than $10 \%$ in all three cases only for the efficiency coefficient, which was then eliminated. The next step was to calculate the correlation coefficient between the pairs of indicators in each group.

Based on the values of Pearson's correlation coefficient and coefficient of variation following indicators were selected: current ratio, average collection period, fixed assets turnover, net profit margin, ROA and debt ratio. 
Krstić S., et al: Some Aspects of Business Operations of Serbian Economy in 2017

\section{Results and discussion}

Based on the defined multi-criteria parameters, the ranking of certain groups of business entities by size, economic activity and region they operate in was performed by Visual PROMETHEE program (Academic Edition).

\subsection{Ranking of business entities by size}

In order to perform the comparative analysis of business economy in large, medium, small and micro economic entities, the ranking was performed using PROMETHEE II method. The obtained results are shown in Table 4.

Table 4. Ranking of business entities by size in 2017

\begin{tabular}{|l|c|r|r|r|}
\hline Rank & $\begin{array}{c}\text { Business entities } \\
\text { by their size }\end{array}$ & \multicolumn{1}{|c|}{ Phi+ } & \multicolumn{1}{c|}{ Phi- } \\
\hline 1 & Medium & 0,3975 & 0 & 0,3975 \\
\hline 2 & Small & 0,3330 & 0,0029 & 0,3300 \\
\hline 3 & Large & 0,2004 & 0,1441 & 0,0564 \\
\hline 4 & Micro & 0 & 0,7839 & $-0,7839$ \\
\hline
\end{tabular}

Source: Authors' calculations.

Based on the results, medium companies had the most favourable business economy in 2017 according to all selected ratio numbers. They were followed by small, large and micro business entities, respectively. Micro business entities occupied the most disadvantageous position because only they had the negative preference flow and their positive preference flow was zero.

In order to understand which aspect of business operations had the greatest influence on such order of economic entities, Figure 1 shows advantages and limitations of every type of business entities.

The data in Figure 1 show that small and medium companies had the advantage over large and micro companies for all analysed criteria. Furthermore, medium companies had significantly higher fixed assets turnover and ROA, and because that, they were better ranked than small companies. Large business entities had two serious limitations - low quick ratio and fixed assets turnover, with the negative influence on their position compared to other groups of economic entities. Finally, micro business entities were the worst ranked, since all the analysed aspects of the business economy represented serious limitations for business operations of these economic entities. 
Krstić S., et al: Some Aspects of Business Operations of Serbian Economy in 2017

Figure 1. Advantages and limitations of the analysed business entities based on their size in 2017

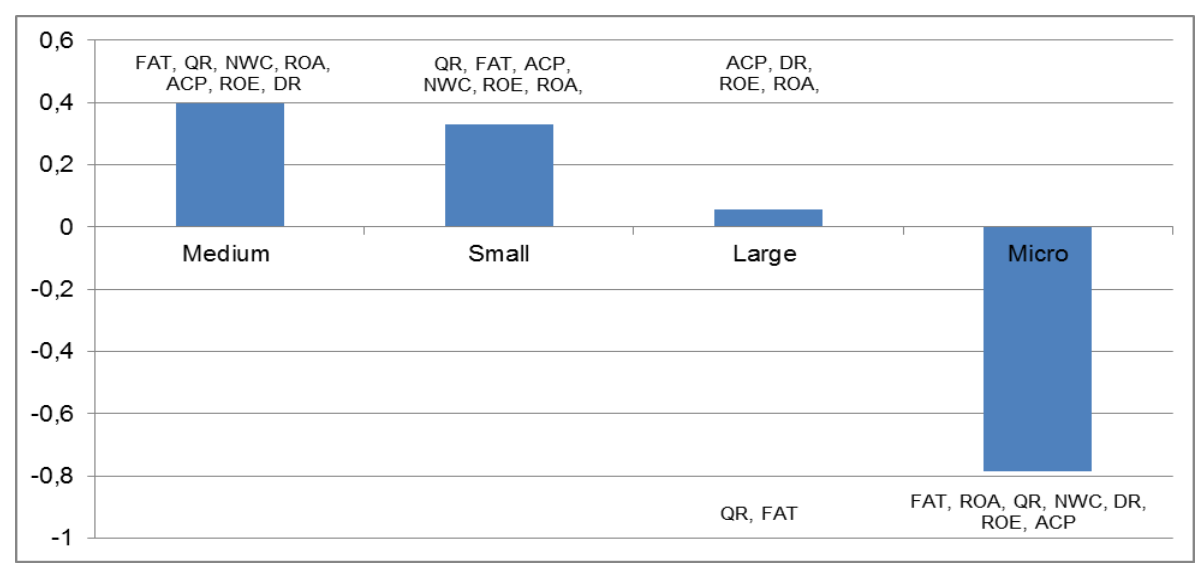

Source: Authors' calculations.

\subsection{Ranking of business entities by economic activity}

The ranking of economic entities by economic activity was performed for the purpose of the comparative analysis of their business economy. The results of the ranking are shown in Table 5.

Table 5. Ranking of business entities by economic activity in 2017

\begin{tabular}{|c|l|r|r|r|}
\hline Rank & Business entities by economic activity & \multicolumn{1}{c|}{ Phi+ } & \multicolumn{1}{c|}{ Phi- } & \multicolumn{1}{l|}{ Phi } \\
\hline 1 & J - Information and communication & 0,4006 & 0,0717 & 0,3290 \\
\hline 2 & B - Mining & 0,2452 & 0,0856 & 0,1596 \\
\hline 3 & $\begin{array}{l}\text { G - Wholesale and retail trade; Repair } \\
\text { of motor vehicles and motorcycles }\end{array}$ & 0,2873 & 0,1409 & 0,1464 \\
\hline 4 & H - Transportation and storage & 0,1908 & 0,1150 & 0,0758 \\
\hline 5 & C - Manufacturing & 0,1766 & 0,1452 & 0,0313 \\
\hline 6 & $\begin{array}{l}\text { M - Professional, scientific and } \\
\text { technical activities }\end{array}$ & 0,1128 & 0,1521 & $-0,0393$ \\
\hline 7 & A - Agriculture, forestry and fishing & 0,0942 & 0,1945 & $-0,1003$ \\
\hline 8 & $\begin{array}{l}\text { E - Water supply; Sewerage, waste } \\
\text { management and remediation }\end{array}$ & 0,1032 & 0,2137 & $-0,1104$ \\
\hline 9 & $\begin{array}{l}\text { D - Electricitity, gas, steam and air } \\
\text { conditioning supply }\end{array}$ & 0,1100 & 0,2669 & $-0,1570$ \\
\hline 10 & F - Construction & 0,0057 & 0,3408 & $-0,3351$ \\
\hline
\end{tabular}

Source: Authors' calculations. 
Krstić S., et al: Some Aspects of Business Operations of Serbian Economy in 2017

Based on the data presented in Table 5, the most favourable business economy was recorded in economic entities from group $\mathrm{J}$, followed by companies in groups $B, G, H, C, M, A, E, D$ and $F$. If the obtained net preference flows is considered, it can be noted that the first 5 groups of business entities had positive net preferences flow, while in the last five groups, the limitations in their business operations surpassed the advantages, so they had negative flow of preferences.

In order to determine the reasons for such order of economic entities by economic activity, Figure 2 shows the advantages and limitations of each group of enterprises.

Figure 2 shows that the economic entities in the field of Information and Communication were the best ranked due to the advantages in all analysed aspects of doing business, except for the debt ratio and fixed assets turnover. Business entities operating in the next three fields - B, $G$ and $H$ had more advantages than limitations. The limitations of these economic entities mostly relate to high indebtedness, low fixed assets turnover and low net profit margin. Business entities in sectors $C, M, A, E$ and $D$ had more limitations than advantages, which was why they were among the worse ranked companies. Business entities in groups $\mathrm{C}$ and $\mathrm{M}$ had three advantages, and the common thing for them was they had high ROE and net working capital.

Figure 2. Advantages and limitations of the analysed business entities based on their economic activity in 2017

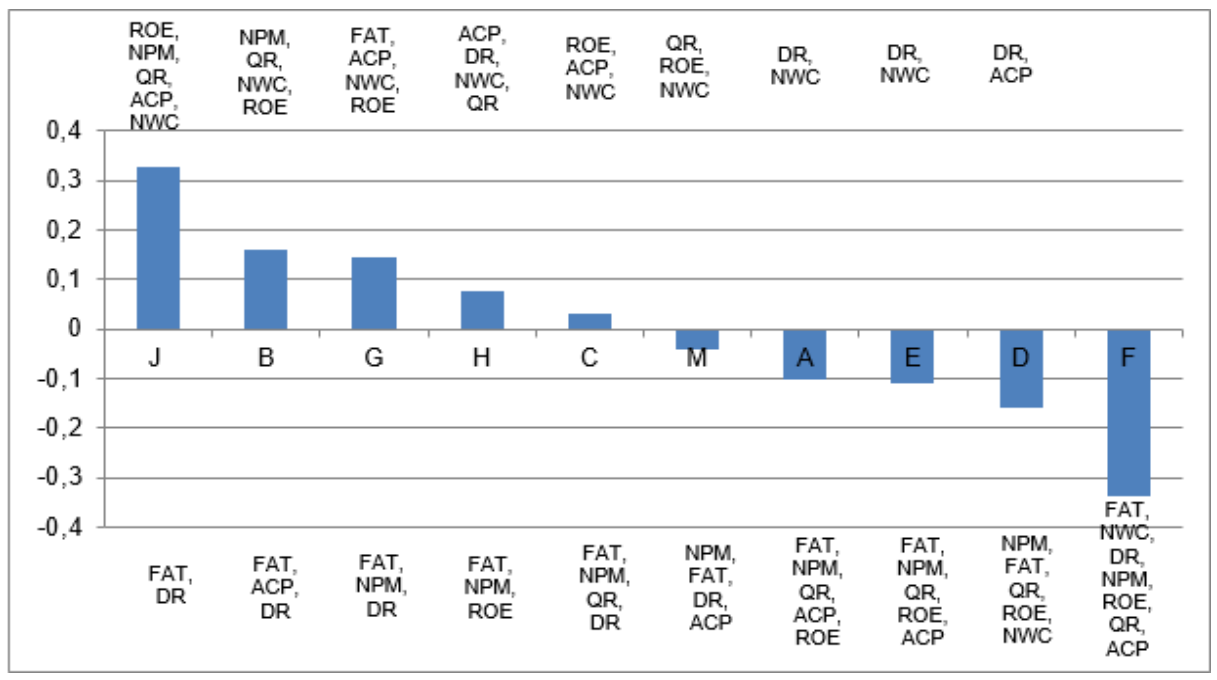

Source: Authors' calculations. 
Krstić S., et al: Some Aspects of Business Operations of Serbian Economy in 2017

The remaining three groups of business entities had two advantages and their common characteristic was low level of indebtedness. The worst ranked business entities were those operating in the field of construction, given that all the analysed aspects of doing business were seen as serious limitations.

\subsection{Ranking of business entities by regions}

The comparative analysis of doing business in different regions in Republic of Serbia was performed by the ranking of business entities based on selected ratios. The results are shown in Table 6.

Table 6. Ranking of business entities by regions in 2017

\begin{tabular}{|c|r|r|r|r|}
\hline Rank & $\begin{array}{c}\text { Business entities according to } \\
\text { region they operate in }\end{array}$ & Phi+ & Phi- & Phi \\
\hline 1 & Region of Vojvodina & 0,3350 & 0,0153 & 0,3197 \\
\hline 2 & $\begin{array}{c}\text { Region of Southern and Eastern } \\
\text { Serbia }\end{array}$ & 0,2631 & 0,0339 & 0,2292 \\
\hline 3 & $\begin{array}{c}\text { Region of Sumadija and } \\
\text { Western Serbia }\end{array}$ & 0,2020 & 0,0648 & 0,1372 \\
\hline 4 & Region of Belgrade & 0,1730 & 0,0839 & 0,0891 \\
\hline 5 & Region of Kosovo and Metohija & 0 & 0,7752 & $-0,7752$ \\
\hline
\end{tabular}

Source: Authors' calculations.

The results in Table 6 show that the best business economy was recorded in economic entities in the region of Vojvodina, followed by companies doing business in the regions of Southern and Eastern Serbia, Sumadija and Western Serbia, Belgrade and Kosovo and Metohija. Furthermore, only economic entities in the region of Kosovo and Metohija had negative net flow of preferences. Positive preference flow amounting zero indicate that business entities in this region did not have advantage in any aspect of business economy in comparison with business entities that operate in other regions.

The key advantages and limitations of business entities in these regions are shown in Figure 3, in order to determine factors which caused such order of economic entities.

Based on Figure 3, it can be concluded that the business entities in Vojvodina and Southern and Eastern Serbia had the advantage over the business entities in other regions according to all analysed ratio indicators except for one - for business entities in Vojvodina this was quick ratio, and for Southern and Eastern Serbia it was the net profit margin. Business entities in Sumadija and Western Serbia and Belgrade occupied the next three positions and they had two limitations. Apart from insufficiently high profitability, expressed by net profit margin, business entities in Sumadija and Western Serbia had low quick 
ratio, while business entities in the region of Belgrade had low fixed assets turnover. For the worst ranked business entities, which operate in Kosovo and Metohija, all analysed aspects were seen as serious limitations.

Figure 3. Advantages and limitations of the analysed business entities based on the region in 2017

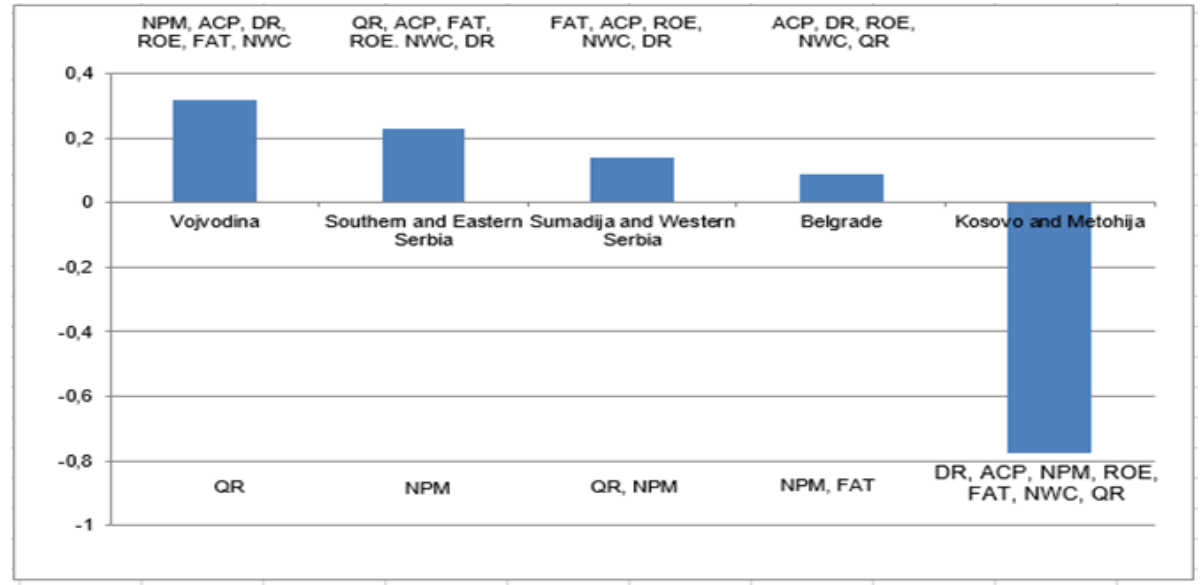

Source: Authors' calculations

\section{Conclusion}

During 2018 the further growth of economic activities in the Republic of Serbia is continued. However, economic growth, observed by individual segments of the economy, is different. Some economy segments record impressive results, achieving stable and sustainable development, and significantly contribute to overall economic development, while in some segments the situation remains unfavourable. In order to examine which economic entities had the greatest contribution to the economic growth, the ranking of business entities was preformed based on their size, economic activity and region in which they operate. The obtained results indicate that the most favourable business economics was recorded by the medium-sized enterprises and enterprises that are operating in the Information and communication sector in Vojvodina. On the other hand, micro business entities, those operating in the field of construction and in Kosovo and Metohija were in the most unfavourable economic and financial position. Bearing this in mind, it is necessary to define measures that will improve the business operations in all economic entities in the future, especially those who have an unfavourable business economy. 
Although 2016 was declared as a year of entrepreneurship (which implied the implementation of appropriate support measures for entrepreneurs), micro enterprises, as a group of enterprises in which entrepreneurs are classified, still face many restrictions in the business. In order to support the growth and development of this segment of the economy, policymakers should implement the appropriate set of measures, such as the development and efficient implementation of microfinance regulations, reducing tax burden, approving tax reliefs, simplifying administrative procedures for paying taxes, encouraging the association of micro-business entities in clusters for the purpose of joint market appearance, improving the regulatory framework for the development of new financial instruments (such as crowd funding) and the like.

Construction companies encountered numerous problems in doing business, not only in 2017, but for a long time, which can be merely solved by the active state support. Bearing in mind that the government is one of the generators of illiquidity problem, state institutions should pay their debts to this sector for the completed works on the construction of public infrastructure in time, and one of the efficient solutions could be the introduction of the so-called "project financing" of infrastructure projects. Having in mind that this activity has significant export potential, it is necessary to provide support for exports through the provision of state guarantees for loans taken for the realization of projects in foreign markets. In addition, it is necessary to formulate and approve appropriate tax reliefs to this sector that would be in line with the specifics of this industry (primarily reducing the earning taxes and excluding reinvested profits from taxation) and provide more favourable conditions for the usage of factoring and forfeiting (bearing in mind that the debt collection period in this activity is too long).

When it comes to the improvement of the business economy in the region of Kosovo and Metohija, the measures to be implemented are primarily based on improving the institutional infrastructure, such as reducing tax burden, simplifying procedures for paying taxes, improving the regulations in the field of payment operations, establishing an electronic system of payment, the development of the financial sector and the like. However, given the specific economic and political situation in the region, the improvement of the business environment requires a longer period of time and the involvement of a numerous institutions. Measures that can be implemented in the short term are aimed at encouraging the association of enterprises into clusters and business communities (for the purpose of joint appearance before state bodies and in both domestic and foreign market), their connection with economic entities in the region of Sumadija and Western Serbia and providing more favourable financing conditions by the state (in the form of subsidized loans). 
Finally, it should be noted that, in order to achieve economic growth in the long run, it is necessary to conceive and implement a set of systemic measures aimed at neutralizing the identified limits of each segment of the economy individually, as well as strengthening the advantages of each of them. This would ensure balanced regional development, neutralization of structural imbalances in the economy and diversification of the economic structure.

Note: Detailed description of the methodology can be obtained from corresponding author, upon request.

\section{References}

Andreopoulou, Z., Koliouskaa, C., Galariotisb, E., \& Zopounidis, C. (2018). Renewable energy sources: Using PROMETHEE II for ranking websites to support market opportunities. Technological Forecasting \& Social Change, 131, 31-37.

Aničić, J., Simić, N., Petrović, V., \& Aničić, D. (2017). Financial aspects of current assets management in Serbian economy. Journal of Process Management, 5(2), 36-44.

Araz, C., \& Ozkarahan, I. (2007). Supplier evaluation and management system for strategic sourcing based on a new multicriteria sorting procedure. International Journal of Production Economics, 106(2), 585-606.

Ćuzović, S., Mladenović, I., Sokolov Mladenović, S., \& Ćuzović, Đ. (2012). Business performances of the Serbian trade sector in conditions of internationalization. Industry, 40(4), 41-61.

Đuričin, D. (2016). A sequenced reforms agenda for Serbia: Tailoring the concepts and instruments. Journal of Business Economics and Management, 65(1-2), 1-24.

Đuričin, D., \& Vuksanović, I. (2014). How to be ahead of the curve: The role of politicians in Serbia's reindustrialization. Journal of Business Economics and Management, 62(1-2), 1-20.

Erić, D., \& Stošić, I. (2015). Debt to equity swaps as alternative of financial restructuring in Serbian economy. In X. Richet, H. Hanić \& Z. Grubišić (Eds.), New economic policy reforms (pp. 244-258). Belgrade, Serbia: Belgrade Banking Academy.

Fura, B., Wojnar, J., \& Kasprzyk, B. (2017). Ranking and classification of EU countries regarding their levels of implementation of the Europe 2020 strategy. Journal of Cleaner Production, 165, 968-979.

Havrylyshyn, O., \& Wolf, T. (1999). Determinants of growth in transition countries. Finance \& Development, 36(2), Retrieved from http://www.imf.org/external/pubs/ft/fandd/1999/06/havrylys.htm

Hellwig, Z. (1974). A method for the selection of a "compact" set of variables. Reports and papers in social sciences. Social Indicators: Problems of Definition and of Selection. 30, 11-20.

Hwang, C. L., \& Yoon, K. (1981). Multiple Attribute Decision Making-Methods and Applications. A State-of-the-Art Survey. New York, United States: Springer Verlag. 
Krstić S., et al: Some Aspects of Business Operations of Serbian Economy in 2017

Ishizaka, A., \& Nemery, P. (2013). Multi-Criteria Decision Analysis: Methods and Software. Chichester, West Sussex, United Kingdom: Wiley.

Kuč, V. (2015). The analysis of financial structure in the largest enterprises in Serbia. Journal of Business Economics and Management, 63(7-8), 399-412.

Lopes, A., P. F., Muñoz, M. M., \& Alarcón-Urbistondo, P., (2018). Regional tourism competitiveness using the PROMETHEE approach. Annals of Tourism Research, 73, 1-13.

Malinić, D. (2013). Insufficiency of Serbian economy's operating performances: Manifestations, causes and main guidelines of recovery. Journal of Business Economics and Management, 61(1-2), 41-62.

Malinić, D., \& Milićević, V. (2012). Overcoming Financial Structural Disorders as a Prerequisite for Strengthening The Competitiveness of Serbian Economy. Journal for Economic Theory and Practice and Social Issues, 61(3-4), 173-183.

Malinić, D., Milićević, V., \& Glišić, M. (2014). Interdependence of enterprise size and vitality in Serbian economy. Journal of Business Economics and Management, 62(7-8), 323-347.

Marasović, B., \& Babić, Z., (2011). Two-step multi-criteria model for selecting optimal portfolio. International Journal of Production Economics, 134(1), 58-66.

Milojević, M., \& Terzić, I. (2015). Liquidity of large companies in the Republic of Serbia. Journal for Economic Theory and Practice and Social Issues, 61(3-4), 173-183.

National Bank of Serbia. (2017). Annual Financial Stability Report. Retrieved from https://www.nbs.rs/internet/latinica/90/90_2/finansijska_stabilnost_2017.pdf

Raćić, Ž., Barjaktarović, L., \& Zeremski, A. (2011). Analysis of indebtedness impact on the profitability of successful domestic companies in the financial crisis. Industry, 39(3), 45-60.

Serbian Business Registers Agency. (2018). Financial statements annual bulletin. Retrieved

from http://www.apr.gov.rs/Portals/0/GFI\%202018/Bilten2017.pdf?ver=2018-04-24121540-370

Serbian Business Registers Agency. (2018). Report on business operations of the Economy in the Republic of Serbia. Retrieved from http://www.apr.gov.rs/Portals/0/GFI\%202018/Saopstenje\%2019062018.pdf

Serbian Business Registers Agency. (2018). Report on business operations of the Economy in the Republic of Serbia. Retrieved from http://www.apr.gov.rs/Portals/0/GFI\%202018/Saopstenje\%2019062018.pdf

Zeleny, M. (1982). Multiple Criteria Decision Making. New York, United States: McGraw-Hill.

Zou, Z., Yun, \& Y., Sun, J. (2006). Entropy method for determination of weight of evaluating indicators in fuzzy synthetic evaluation for water quality assessment. Journal of Environmental Sciences, 18(5), 1020-1023. 